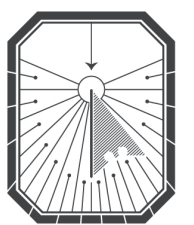

KYIV-MOHYLA

LAW \& POLITICS JOURNAL

KYIV-MOHYLA SCHOLARLY PEER-REVIEWED JOURNALS

Cosmopolitanism and Nationalism: A Critique of the Effectiveness of the International Refugee Regime

Author(s): Ivan Ng Yan Chao

Source: Kyiv-Mohyla Law and Politics Journal 6 (2020): 159-176

Published by: National University of Kyiv-Mohyla Academy

http://kmlpj.ukma.edu.ua/ 


\title{
Cosmopolitanism and Nationalism: A Critique of the Effectiveness of the International Refugee Regime
}

\author{
Ivan Ng Yan Chao \\ Postgraduate Student Research Assistant \\ Nanyang Technological University, Singapore
}

\begin{abstract}
The past few years have seen the issue of refugees rise in prominence, particularly in Europe but also in other parts of the world. It has been almost seven decades since the United Nations High Commissioner for Refugees was set up and the first international treaty regulating the issue of refugees signed. This article examines the international legal framework governing the issue of refugees and argues that it is ineffectual because refugees are inherently a matter of high politics — refugees are fundamentally a political issue subject to the vicissitudes of politics. The moral and economic justifications for the international refugee regime are also highly contested, and this contestation plays out in the political realm. The international refugee regime and legal regulation of the issue is unlikely to be effective for as long as the nation-state continues to be the primary actor in the international world order. This is because the international refugee regime requires enforcement by states to be effective-however, political, moral and economic vicissitudes across the states involved impede its ability to function in its ideal conception.
\end{abstract}

Key Words: refugees, migration, politics, international law, philosophy, nation-state

The issue of refugees has been of increasing significance in recent years. The UNHCR estimated that at the end of 2016, 65.6 million individuals were forcibly displaced worldwide, of whom 22.5 million were refugees, the highest figure ever recorded. ${ }^{1}$ Refugees can be found all across the world, making it no doubt an issue of global significance. What role is law likely to play with respect to this issue? This essay seeks to argue that although an international refugee regime exists as a form of normative ordering in relation to the issue of refugees, it is ineffectual, and the issue is dominated by political considerations, which includes both moral and economic issues. The issue of refugees highlights the continued centrality and importance of the nation-state paradigm even as globalization appears to be eroding it. This paper is divided into three sections. In Section I, I first consider and evaluate the existing legal framework in relation to refugees. In Section II, the ways in which political, moral and economic considerations heavily influence (or even take precedence over) legal considerations

$1 \quad$ United Nations High Commissioner for Refugees, “Global trends — forced displacement in 2016," last modified June 19, 2017, accessed January 14, 2020, http://www.unhcr.org/5943e8a34.pdf. 
in relation to refugees will be examined. Section III will then look at how theories of novel forms of legal regulation can be applied to the refugee context, before I conclude with my views on how the legal treatment of the issue is likely to develop.

\section{Section I: The International Refugee Framework}

As a branch of international law, refugee law is primarily grounded in two treaties - the 1951 Refugee Convention ${ }^{2}$ and the ${ }_{1967}$ Protocol. ${ }^{3}$ A refugee is defined in Article 1 (A) 2) of the 1951 Refugee Convention to be a person who "owing to well-founded fear of being persecuted for reasons of race, religion, nationality, membership of a particular social group or political opinion, is outside the country of his nationality and is unable or, owing to such fear, is unwilling to avail himself of the protection of that country; or who, not having a nationality and being outside the country of his former habitual residence as a result of such events, is unable or, owing to such fear, is unwilling to return to it." 4 The main international institution responsible for refugee issues, the Office of the United Nations High Commissioner for Refugees ("UNHCR"), was created in 1950. ${ }^{5}$ The UNHCR, as the "guardian of the wider global refugee regime," 6 has two core mandates - working with states to ensure refugee protection, and ensuring durable solutions either in the country of origin of refugees or in the new country they are in. ${ }^{7}$

A person is a refugee by virtue of meeting this definition as a matter of fact ${ }^{8}$ thus, the formal determination, usually by a state, of whether any given person meets the definition does not grant the person refugee status from that point onwards, but is said to be "purely declaratory in nature." 9 Prior to formal determination, however, refugees are considered asylum-seekers. Asylum-seekers may or may not be actual refugees but are generally recognized under refugee law as having a right to apply for asylum. ${ }^{10}$ The principle of non-refoulement has been argued to be the "core element"11

2

United Nations General Assembly, “Convention Relating to the Status of Refugees,” 28 July 1951, accessed January 14, 2020, http://www.unhcr.org/3b66c2aa1o.pdf.

United Nations General Assembly, "Protocol Relating to the Status of Refugees," 31 January 1967, accessed January 14 2020, http://www.unhcr.org/3b66c2aa1o.pdf.

United Nations General Assembly, "Convention Relating to the Status of Refugees."

Alexander Betts, Gil Loescher, James Milner and Gilburt Damian Loescher, UNHCR: The Politics and Practice of Refugee Protection (New York: Routledge, 2012), 1.

Betts et al., UNHCR, 2.

Betts et al., UNHCR, 2.

James Mansfield, “Extraterritorial Application and Customary Norm Assessment of Non-Refoulement: The Legality of Australia's Turn-Back Policy," The University of Notre Dame Australia Law Review 17 (2015).

Mansfield, "Extraterritorial Application," 52.

William Thomas Worster, "The Contemporary International Law Status of the Right to Receive Asylum," International Journal of Refugee Law 26 (2014): 480.

Seunghwan Kim, "Non-Refoulement and Extraterritorial Jurisdiction: State Sovereignty and Migration Controls at Sea in the European Context," Leiden Journal of International Law zo, 
of refugee law - it prohibits states which are parties to the $195^{1}$ Refugee Convention from expelling or returning refugees back to a country where they will face danger, and this country they are sent back to need not be their country of origin. ${ }^{12}$ What nonrefoulement means is that the moment asylum-seekers are within a state's territory, the state is prohibited under refugee law from removing them from the territory unless they have been confirmed not to be refugees - because of the risk that in removing these asylum-seekers from the territory, some genuine refugees amongst them would be sent back and face danger. ${ }^{13}$ There are, however, national security and public order exceptions found in Articles 32 and 33 of the 1951 Refugee Convention, allowing states to expel refugees on these grounds.

Three observations can be made at this point. Firstly, the international refugee regime would appear to challenge a fundamental aspect of the international order, the sovereignty of individual nation-states. ${ }^{14}$ Sovereignty is said to be the "grundnorm of international society" 15 of which the ability to control one's borders and exclude aliens from it is a key aspect. ${ }^{16}$ While it is recognized that globalization has certainly eroded national sovereignty, ${ }^{17}$ border controls remain "one of the few remaining ways in which states can assert their independence"18 amidst globalization. While it is mandatory to recognize refugee status, ${ }^{19}$ there is no duty to grant asylum, that being purely within the state's "discretionary prerogative." ${ }^{20}$ Thus, even adopting a purely legal analysis, there is a tension or even outright conflict between the two legal principles of refugee protection under refugee law and the sovereignty of states — the refugee claims a right to safety, while the sovereign nation-state claims a right to control its borders. ${ }^{21}$ Secondly, nation-states are central to the international refugee regime. As Jeremy Waldron notes,

no. 1 (2017): 49 .

12 Mansfield, "Extraterritorial Application," 53.

13 Peter H. Schuck, "Refugee Burden-Sharing: A Modest Proposal," Yale Journal of International Law 22 (1997): 245 .

14 Julian Ku and John Yoo, "Globalization and Sovereignty," Berkeley Journal of International Law $3^{1}$ (2013): 211 .

15 Carrie Booth Walling, "Human Rights Norms, State Sovereignty and Humanitarian Intervention," Human Rights Quarterly 37 (2015): 386.

16 Attila Ataner, "Refugee Interdiction and the Outer Limits of Sovereignty," Journal of Law \& Equality 3, no. 1 (2004): 8.

17 Virginie Guiraudon and Gallya Lahav, "A Reappraisal of the State Sovereignty Debate: The Case of Migration Control," Comparative Political Studies 33, no. 2 (2000): 164.

18 Harald Bauder, “Understanding Europe’s Refugee Crisis: A Dialectical Approach,” Geopolitics, History and International Relations 8, no. 2 (2016): 69.

19 Worster, "Right to Receive Asylum," 477.

20 Worster, "Right to Receive Asylum," 477.

21 Catherine Dauvergne, "The Dilemma of Rights Discourses for Refugees," University of New South Wales Law Journal 23 (2000): 57. 
states are both the main sources and main coercive enforcers of international law, ${ }^{22}$ which includes refugee law. Internationally recognized human rights, including the rights of refugees, "remain dependent on national legal systems." ${ }^{33}$ This is a view echoed by Joseph Raz as well, who argues for the continued centrality of the state because "there is no single institution that appears likely to replace the state." ${ }^{4}$ Thirdly, the international refugee regime has been argued to demonstrate Kantian cosmopolitan ideals of cooperation and a concept approaching that of global citizenship. ${ }^{25}$

\section{Section II - the Effect of Political, Moral and Economic Considerations on the International Refugee Regime}

\section{Political considerations}

Bearing in mind the three observations about the tension between refugee law and sovereignty, and the importance of the state in refugee law, I now consider how extra-legal considerations affect the legal regulation of refugees. I would argue that the refugee law regime, since its inception and up to the present day, remains very much dominated by politics. Chimni emphasizes the importance of historical and political context despite refugee law's tendency to be blind to it due to positivism's influence. ${ }^{26}$ The modern refugee law regime was intimately linked to Cold War concerns - it was part of a strategy by Western nations to score political and ideological points against Communism by accepting refugees fleeing persecution in the communist states. ${ }^{27}$ The end of the Cold War meant the disappearance of such political incentives to continue accepting refugees. Chimni puts forth a realist view, which is that international regimes, including the refugee law regime, only come into existence when it is in the interests of a coalition of powerful states to create such a regime, and continues to exist insofar as it continues to serve the interests of these powerful states. ${ }^{28}$ This has echoes of the view found in the "ideology critique" of heterodox legal scholarship, ${ }^{29}$ which posits that seemingly objective criteria in legal doctrine "in fact serve the dominant interests in society which that doctrine protects," 30 although the difference here is that we are looking globally rather than at the level of a particular society.

22 Jeremy Waldron, "Are Sovereigns Entitled to the Benefit of the International Rule of Law?,

European Journal of International Law 22, no. 2 (2011): 319.

Dauvergne, "Dilemma of Rights Discourses," 57.

Joseph Raz, "Why the State?" King's College London Law School Research Paper 2014-38, $2013,17$.

Matthew C. Altman, "The Limits of Kant's Cosmopolitanism: Theory, Practice, and the Crisis in

Syria," Kantian Review 22, no. 2 (2017): 193.

Bhupinder S. Chimni, “The Geopolitics of Refugee Studies: A View from the South," Journal of

Refugee Studies 11 (1998): 355 .

Chimni, "The Geopolitics of Refugee Studies," 355.

Chimni, "The Geopolitics of Refugee Studies," 366.

Andrew Halpin, “Ideology and Law," Journal of Political Ideologies 11, no. 2 (2006): 16o.

Halpin, "Ideology and Law", 16o. 
More fundamentally, the refugee issue will arguably always be intimately linked to politics because it raises uncomfortable questions about the relationships between the state, citizens and outsiders. Jeremy Waldron notes that states are not ends in themselves, but exist "for the sake of human individuals" 31 _ but which individuals count? Matthew Gibney observes that almost all modern states claim to be more than merely groups of people desiring protection against a Hobbesian state of nature - they claim to represent distinct peoples possessing unique characteristics. ${ }^{32}$ States provide an answer to the difficult question of who is responsible to whom in the world - states are seen as responsible to their own citizens. ${ }^{33}$ Thus, it is expected that the interests of citizens will be prioritized, such that states are "highly resistant to the moral claims of outsiders" 34 and "it is normal and acceptable for states to discriminate between their own citizens and others." 35 The line between citizens and non-citizens demarcates rights-bearing "haves" from "have-nots." 36 The idea of citizenship, who "we the people" are as members of a political community, in itself already a contested concept, becomes further shaken up with the "incursion" 37 of the refugee into that community. As such, the refugee issue is an inherently political and politicized issue, impinging on questions of national identity and belonging. Amidst the forces of globalization which nation-states can do little to influence, stopping refugees from entering a nation-state is, as Zygmund Bauman notes, a way to "relieve, at least for a time, the humiliation of our helplessness and our incapacity to resist the disabling precariousness of our own place in the world." 38

As a matter of practice, given the central role individual states play in relation to the functioning of the international refugee regime, politics of the state is bound to affect the way refugees are dealt with. Political discourse about refugees appears to fall into two opposing ideological positions — nationalism and cosmopolitanism. Nationalist political discourse, emphasizing cultural identity and the fortification of national borders, ${ }^{39}$ has been gaining popularity across much of the Western world. Recent developments such as the rise of far-right parties in Europe and the rightward drift of European political

$31 \quad$ Waldron, "Are Sovereigns Entitled," 325.

32 Matthew J. Gibney, The Ethics and Politics of Asylum: Liberal Democracy and the Response to Refugees (Cambridge University Press, 2004), 204.

33 Gibney, The Ethics and Politics of Asylum, 211.

34 Gibney, The Ethics and Politics of Asylum, 211.

35 Barry Hindess, "Divide and Rule - The International Character of Modern Citizenship," European Journal of Social Theory 1, no. 1 (1998): 62.

36 Feyzi Baban and Kim Rygiel, "Living with others: fostering radical cosmopolitanism through citizenship politics in Berlin," Ethics \& Global Politics 10, no. 1 (2017): 101. Andrew Benjamin, "Refugees, Cosmopolitanism and the Place of Citizenship," Architectural Theory Review 7, no. 2 (2002): 105.

38 Elizabeth Keyes, "Unconventional Refugees," American University Law Review 67 (2017): 130.

39 Jessica Gerrard, "The refugee crisis, non-citizens, border politics and education," Discourse: Studies in the Cultural Politics of Education 38, no. 6 (2017): 883. 
elites, ${ }^{40}$ US President Donald Trump's policies of tightening the border with Mexico ${ }^{41}$ and ban on travelers from certain Muslim states, ${ }^{42}$ and Australia's military operation to stop asylum-seekers from reaching Australian territory ${ }^{43}$ all highlight an upsurge in a political outlook hostile to refugees. Populist nationalists are able to tap into deepseated resentment, fear and disillusionment with globalization to inspire hatred of outsiders. ${ }^{44}$ Cosmopolitan approaches, however, are quite the opposite, influenced by Kantian ideas of "world citizenship and universal hospitality towards foreigners, crossing the geo-political borders of nation-states." 45 Germany under Chancellor Merkel could be seen as an example of this, espousing an "open-door" policy ${ }^{46}$ and taking in an unprecedented number of refugees. ${ }^{47}$ There is thus a dichotomy in the political realm (nationalism vis-à-vis globalism) which mirrors the legal tension (sovereignty vis-à-vis refugee rights). As James Hathaway observes, the fact that the international refugee regime is designed and administered by states means that "the availability and quality of protection vary as a function of the extent to which the admission of refugees is perceived to be in keeping with national interests" 48 (emphasis added). Indeed, it is not a case of politics being necessarily at odds with the legality of state actions - a political leader who is against the entry of refugees can argue that there is a legal basis for policies to prevent refugees from entering - which is that of state sovereignty. Depending on the political inclinations of individual leaders and the ideological position taken by the state towards refugees, very different approaches could be adopted by the leaders of the state possessing decision-making and policy-making power, demonstrating the centrality of politics when it comes to this issue.

40 Ari Hirvonen, "Fear and Anxiety: The Nationalist and Racist Politics of Fantasy," Law Critique 28, no. 3 (2017): $25^{2}$.

41 David Agren, “'Bad hombres': reports claim Trump spoke of sending troops to Mexico," The Guardian, February 2, 2017, https://www.theguardian.com/us-news/2017/feb/o2/bad-hombres-reports-claim-trump-threatened-to-send-troops-to-mexico. BBC, “Trump Travel Ban Comes into Effect for Six Countries,” June 30, 2017, http://www.bbc. com/news/world-us-canada-4045236o.

43 Joyce Chia, Jane McAdam and Kate Purcell, "Asylum in Australia: 'Operation Sovereign Borders' and International Law," Australian Yearbook of International Law 32 (2014): 35 .

44 Siobhan Kattago, "The End of the European Honeymoon?: Refugees, Resentment and the Clash of Solidarities," Anthropological Journal of European Cultures 26, no. 1 (2017): 5 o.

45 Marina Calloni, "Cosmopolitanism and the Negotiation of Borders," Irish Journal of Sociology 20, no. 2 (2012): 159 .

46 Florian Trauner and Jocelyn Turton, “"Welcome culture”: The Emergence and Transformation of a Public Debate on Migration," Österreichische Zeitschrift für Politikwissenschaft 46, no. 1 (2017): 36 .

47 Suman Momin, "A Human Rights Based Approach to Refugees: A Look at the Syrian Refugee Crisis and the Responses from Germany and the United States," Duke Forum for Law and Social Change 9 (2017): 67 .

48 James C. Hathaway, "A Reconsideration of the Underlying Premise of Refugee Law," Harvard International Law Journal 31 (1990): 175 . 


\section{Moral considerations}

The issue of refugees is also closely linked to questions of morality and plays a vital role in relation to the both the normative justifications for the international refugee regime as well as the political arguments made on either side. It can perhaps be distilled into a fundamental moral question - what moral duties do states owe to noncitizens? Two contrasting moral positions can be observed - impartialist and partialist. An impartialist approach emphasizes the universal nature of the requirements of morality. ${ }^{49}$ Moral duties are owed to all humans simply because they are humans - it is not morally permissible to prioritize certain people over others when deciding who to help-all persons have equal claim to our moral concern..$^{50}$ Carens, building upon the ideas of John Rawls, applied the Rawlsian concepts of the "original position" and "veil of ignorance" on a global level, ${ }^{51}$ and concluded that state borders were not morally justified, acting as "feudal birthright privileges ... locking citizens of certain countries into relative privilege and citizens of other countries into poverty and danger." ${ }^{2}$ If we started from the original position and behind the veil of ignorance, Carens argues we would not want borders to exist, given the massive inequalities which exist in the world today. If it is thus accepted that nationality is a morally arbitrary trait, 53 then it follows that states have the same moral duties towards non-citizens as they have towards their own citizens, ${ }^{54}$ and states should thus open their borders to refugees. Indeed, the utilitarian moral philosopher Peter Singer adopts an even more extreme position-morality requires everyone to work full-time to relieve suffering taking place across the world. ${ }^{55}$ In the refugee context, he argues that states have a moral duty to keep accepting refugees until problematic luxuries had been eliminated and further acceptance of refugees would cause danger and insecurity to the state. ${ }^{56}$ Impartialist moral positions would thus reject the primacy of the legal principle of state sovereignty (to differing degrees), and instead, support the international refugee regime. Some theorists even argue that morality is particularly wedded to refugee law, that "the origins of refugee law demand therefore that legal competence track moral competence." ${ }^{57}$

Yet there is also a competing moral view which opposes impartialism, that of partiality. Partiality asserts that, all else being equal, it is morally right to act in a way

49 Gibney, The Ethics and Politics of Asylum, 63.

50 Gibney, The Ethics and Politics of Asylum, 63.

$5^{1} \quad$ Keyes, "Unconventional Refugees," 120.

52 Keyes, "Unconventional Refugees," 120.

53 Tally Kritzman-Amir and Thomas Spijkerboer, "On the Morality and Legality of Borders: Border Politics and Asylum Seekers," Harvard Human Rights Journal 26, no. 1 (2013): 9.

Kritzman-Amir and Spijkerboer, "Morality and Legality of Borders", 9. Peter Singer, Practical Ethics, $2^{\text {nd }}$ ed. Cambridge: Cambridge University Press, 1993, 261. 
which prioritizes the good of those to whom you have a "special responsibility." 58 Brenda Almond argues that there can be circumstances where discrimination is "practical, logical and morally mandated." 59 She gives the example of a father who prioritizes saving his drowning child over a drowning stranger, or an aid-giver distributing food who prioritizes the weaker recipients over the stronger ones. She criticizes Peter Singer's universalist views as unrealistic because they conflict with "widely-held intuitions." 60 Extrapolating this view to the state level, states are seen as having "special responsibility" to their citizens, morally speaking — states have a duty to provide for their own members. ${ }^{61}$ Christopher Wellman takes the argument even further and concludes that "every legitimate state has the right to close its doors to all potential immigrants, even refugees desperately seeking asylum." ${ }^{2}$ He reaches that conclusion by reasoning from the principle of freedom of association - the belief that "each of us enjoys a morally privileged position of dominion over our self-regarding affairs." ${ }^{63}$ This freedom consists of not only the freedom to associate, but also to disassociate - the freedom to get together entails a corresponding right to exclude certain others. ${ }^{64} \mathrm{~A}$ legitimate state's freedom of association thus entitles it to exclude non-citizens from its territory. ${ }^{65}$

The moral tension between the impartial and partial views would appear to be extremely difficult to reconcile since their starting points are so different. While impartialism emphasizes the moral equivalence of all persons near and far, partialism considers it morally permissible to discriminate, whether due to the existence of "special responsibilities" or based on the freedom of association. This is perhaps a prime example of the incommensurability of values, in the sense of incompatibility as noted by Ruth Chang - impartialist and partialist values could not be fully realized together in the world. ${ }^{66}$ Unless the partialist idea of "special responsibility" is somehow stretched to include all humans (which would mean the responsibility is no longer "special") or the scope of freedom of association greatly reduced, it is difficult to see how impartialist and partialist moral views can co-exist. The moral dichotomy between impartialism and partialism, like the political dichotomy noted earlier, also mirrors the legal dichotomy between refugee rights and state sovereignty.

$5^{8}$ Brenda Almond, "Border Anxiety: Culture, Identity and Belonging," Philosophy 91, no. 4 (2016): 475.

59 Almond, "Border Anxiety," 475.

60 Almond, "Border Anxiety," 476.

61 Gibney, The Ethics and Politics of Asylum, 194.

62 Christopher H. Wellman, "Immigration and Freedom of Association," Ethics 119, no. 1 (2008): 109.

63 Wellman, "Immigration and Freedom of Association," 110.

64 Stuart White, "Freedom of Association and the Right to Exclude," Journal of Political Philosophy 5 (1997): 373 .

65 Christopher H. Wellman, "Freedom of Movement and the Rights to Enter and Exit," in Migration in Political Theory: The Ethics of Movement and Membership, eds. Sarah Fine and Lea Ypi (Oxford University Press, 2016), 3.

66 Ruth Chang, "Incommensurability (and Incomparability)," in The International Encyclopedia of Ethics, ed. Hugh LaFollette (Wiley, 2013). 
Since it is impossible for all in a society to come to a consensus on which moral view is correct, there is bound to be a split in societies regarding which moral view should be preferred when it comes to dealing with refugees. The majority of citizens in a country may be of the opinion that morality requires that the international refugee regime be upheld and refugees allowed to enter the country, but this may not be a view shared by citizens of other countries, and indeed, even within the same country, views on what is moral can change over time. Moral considerations are closely linked to politics, especially in democracies, because politicians would have an incentive to give effect to the views of the majority when it comes to refugees. Indeed, one could easily imagine that a politician who espouses pro-refugee policies in a democratic country where the majority of voters feel that there is no moral obligation owed to refugees would not do well in elections.

\section{Economic considerations}

As Afilalo and Patterson note, the modern nation-state gains its legitimacy by providing security and welfare ${ }^{67}$ Economic strategies could range from cradle-to-grave entitlements as in Europe or centralized industrial planning in Japan, but all major economies have a similar fundamental philosophy, which is "the dedication of the power of the State to secure, as a matter of entitlement, the welfare of the nation." 68 Traditional economic theory regards homo economicus as the starting point for analysis - humans are thought to be rational and self-interested. ${ }^{9}$ Two things can thus be assumed - states have an interest in providing for the welfare of their people, and individual humans are rational and self-interested. The international refugee regime, however, would appear to go against both these things. Adhering to the international refugee regime would mean that states should, as a matter of legal principle, accept as many people who enter as possible, so long as they fit the legal definition of a "refugee."

The economic significance of refugee flows, however, cannot be simply ignored. Properly providing for refugees can be a serious economic burden. ${ }^{70}$ Refugees rely on public services, such as language training, housing, accommodation, schools and access to healthcare, ${ }^{71}$ and this is even worse when the countries receiving refugees are themselves developing states. For example, in light of the Syrian civil war and the exodus of Syrians to neighboring countries, on a per-capita basis, Lebanon, Jordan

67 Ari Afilalo and Dennis Patterson, "Statecraft, Trade and Strategy: Toward a New Global Order," in Theorising the Global Legal Order, eds. Andrew Halpin and Volker Roeben (Hart Publishing, 2009), 128.

68 Afilalo and Patterson, "Statecraft, Trade and Strategy," 129.

69 Toshio Yamagishi, Yang Li, Haruto Takagishi, Yoshie Matsumoto and Toko Kiyonari, "In Search of Homo Economicus," Psychological Science 25, no. 9 (2014): 1699. Tally Kritzman-Amir, "Not in My Backyard: On the Morality of Responsibility Sharing in Refugee Law," Brooklyn Journal of International Law 34 (2009): 375. 
and Turkey have the highest number of refugees in the world today. ${ }^{72}$ That refugees are an economic burden is perhaps exemplified by the acrimonious debates between European Union member states over proposals for "sharing" refugees-with concerns about the impact of refugees on state welfare systems being commonly cited. ${ }^{73}$ From an economic perspective, it would thus appear that, regardless of whether one looks at the situation from the state or individual citizen level, refugees do not appear to make economic sense. States would be less able to provide the same level of economic welfare to citizens because resources have to be diverted for refugee needs, possibly eroding state legitimacy, while individual citizens, as rational and self-interested humans, would presumably be opposed to a situation where they have fewer resources available for their consumption.

The economic concept of cost-benefit analysis is perhaps useful here. Regardless of what the legal position is under the international refugee regime, the refugee situation can be analyzed under cost-benefit analysis in the following mannerwhere the benefits of refusing refugees outweighs the costs, then action is taken to refuse them - otherwise they are allowed entry. ${ }^{74}$ Refusing refugees is a benefit insofar as it prevents the economic burdens due to refugees from arising — and might also allow them to score political points as being "tough" with border security. The costs of contravening the international refugee regime might, however, involve the potential loss of "international reputation, political capital ... and diplomatic influence"75 Ultimately, because it is difficult to "require governments to implement rights perceived by states as fundamentally at odds with their fundamental interests" ${ }^{76}$ due to the lack of coercive mechanisms at the global level, the cost involved when states breach the international refugee regime is unlikely to be perceived by states as being greater than the benefit of compliance.

Legal treatment of the refugee issue is thus likely to be significantly influenced by economic considerations, which influence political decisions. If refugees are such an economic burden, then economic considerations would militate in favor of political leaders adopting anti-refugee policies to prevent more refugees from coming into the country, especially in democratic countries, where political leaders risk being voted out by voters who feel that pro-refugee policies are placing an unfair economic burden on them.

United Nations High Commissioner for Refugees, "Global trends_-forced displacement in 2016," last modified June 19, 2017, accessed January 14, 2020, http://www.unhcr.org/5943e8a34.pdf. Joakim Ruist, “The Fiscal Cost of Refugee Immigration: The Example of Sweden," Population and Development Review 41, no. 4 (2015): 567.

74 Euston Quah and Raymond Toh, Cost-Benefit Analysis: Cases and materials (Routledge, 2011), 3.

75 Thomas Gammeltoft-Hansen and Nikolas F. Tan, "The End of the Deterrence ParadigmFuture Directions for Global Refugee Policy," Journal on Migration and Human Security 5, no. 1 (2017): 44 .

76 James C. Hathaway, The Rights of Refugees Under International Law (Cambridge University Press, 2005), 998. 


\section{Section III: Novel Forms of Legal Regulation}

I now discuss the extent to which novel forms of legal regulation might be involved in the issue of refugees - namely the transmission of law, normativity of law and legal pluralism. Hasegawa emphasizes the importance of "translators" in the adaptation of legal ideas - legal ideas are not simply transplanted from a source, but are reconstructed through a process of translation. ${ }^{77}$ This could be more problematic in cases where there is a difference in cultural values between the source and the society receiving the legal ideas. ${ }^{78}$ More inward-looking societies may possess a cultural aversion to outsiders, including refugees - making it difficult to accept a legal responsibility towards them. If refugee law is the "legal object" that is received by nation-states, then it might be radically changed during and after the reception, because "abstract aspirational norms are concretized and prioritised among the particular competing concerns of a host society." 79 As the examples discussed in the political, moral and economic contexts show, this is arguably true in the case of refugees. The abstract ideals of the international refugee regime, in the process of being received and translated into policy responses by nation-states, end up becoming something possibly quite different altogether. As Hasegawa argues, the actual nature of legal translation is such that there is necessarily a "twist" in meaning after translation. ${ }^{80}$ Similarly, Kahn-Freund stressed the importance of socio-political context when it comes to the transplantation of law-factors like the "prevailing ideology, the political institutions and the interests of the powerful" 81 can be major obstacles to successful transplantation of legal principles — as the preceding discussion on political considerations shows.

MacCormick posits three features of law - law is institutional, authoritative and heteronomous. ${ }^{82}$ Law is institutional in the sense that institutions are required in order for law to apply because it is not self-applying, ${ }^{83}$ and these institutions exist to determine disputes for all persons under their jurisdiction or competence. ${ }^{84}$ It is authoritative because decisions by legal institutions are final and conclusive. ${ }^{85}$ Lastly, flowing from the two preceding characteristics, law is heteronomous, because "it confronts each moral agent with categorical requirements in the form of duties, obligations, and

Legal Order, eds. Andrew Halpin and Volker Roeben (Hart Publishing, 20o9), 91.

78 Hasegawa, "Incorporating Foreign Legal Ideas," 96.

79 Hasegawa, "Incorporating Foreign Legal Ideas," 275.

8o Hasegawa, "Incorporating Foreign Legal Ideas," 100.

81 William Twining, "Social Science and Diffusion of Law," Journal of Law and Society 32, no. 2 (2005): 210.

82 252.

83 MacCormick, Institutions of Law, 258.

84 MacCormick, Institutions of Law, 252.

85 MacCormick, Institutions of Law, 254. 
prohibitions that purport to bind the agent regardless of the agent's own rational will as an autonomous moral being." 86 These characteristics may be an accurate description of law at the nation-state level, but transposing these ideas about the normativity of law to global legal phenomena like the refugee issue raises some striking differences. All three of MacCormick's features would appear to be conspicuously absent in the international refugee regime. While independent institutions exist, most notably the UNHCR, refugees are still reliant on sovereign nation-states to give effect to their rights under refugee law. Without institutions to make decisions apart from those which are part of nation-states, there can be no authoritative decisions to begin with. As MacCormick notes, legal determinations within the nation-state paradigm have the backing of state power, which "bears significantly on vital interests of the persons whom legal determinations are addressed." ${ }^{77}$ Instead, the international refugee regime appears to be unable to bind the autonomous wills of nation-states, raising questions as to the normativity of the international refugee regime compared to state law.

Gillespie suggests the idea of understanding global legal phenomena as "global scripts." ${ }^{88}$ Global scripts are regulated at three levels of regulatory community 89 the formal level, the unofficial level and through public discourse. All three levels are present in the refugee issue. State regulation and public discourse have been alluded to earlier - states are the primary actors in the international refugee regime, and there is much public discourse about refugees mainly with respect to political, moral and economic considerations. At the unofficial level, numerous refugee NGOs exist -indeed, much of the groundwork of the UNHCR relies on collaboration with such NGOs. ${ }^{90}$ These different levels of regulatory community interact to provide an end-result - the ultimate manner in which the issue is dealt with, whether it is convergence with, or departure from, global scripts. Gillespie's conceptualization of global scripts and regulatory communities is thus rather useful for understanding why the international refugee regime is in its present state - by reference to not just the state, but (especially) public discourse within states. Some countries, like Germany with its "open-door" policy, have regulatory communities which are more inclined to adhere to global scripts, while others do not.

As Halpin notes, global legal phenomena can be "troubling" because of the "inability of the state to control their status and impact as law." ${ }^{91}$ An issue arises as to the relationship between global legal phenomena and state law - and legal pluralism is proposed as a possible answer - to recognize overlapping types of laws affecting

86 MacCormick, Institutions of Law, 255.

87 MacCormick, Institutions of Law, 255 .

88 John Gillespie, "Developing a Framework for Understanding the Localisation of Global Scripts in East Asia," in Theorising the Global Legal Order, eds. Andrew Halpin and Volker Roeben (Hart Publishing, 2009), 209.

89 Gillespie, "Developing a Framework," 215.

90 United Nations High Commissioner for Refugees, "Non-Governmental Organizations," accessed January 14, 2020, http://www.unhcr.org/non-governmental-organizations.html. 
the lives of subjects. ${ }^{92}$ The problem, however, as Twining argues, is that expanding the idea of "law" to include non-state, global legal phenomena risks including many things which should not be there, such as culture, traditions and religion..$^{93}$ Joseph Raz thus argues for the centrality of the state in the global legal order, because the state remains "the most comprehensive legally-based social organization of the day" ${ }^{44}$ The global legal order has generally failed to attain legitimacy through the respect and loyalty of people around the world - in contrast to how states have managed to instill nationalist pride in their citizens..$^{95}$ Raz's view of the global legal order arguably applies particularly so in relation to the international refugee regime. As I had sought to demonstrate in my earlier discussion on the political, moral and economic influences on the international refugee regime, the nation-state continues to occupy a position which the international refugee regime does not. Although state legal systems may partially recognize the normative power of external systems over certain specific matters (such as refugees), state legal systems deny external systems general power. It is of course possible for state legal systems to be seen as subordinate to international tribunals - especially by "oppressed and discriminated individuals" 96 such as refugees — but, as MacCormick argues, it is the state systems which possess coercive power to give effect to legal rights, ${ }^{97}$ and not the international refugee regime.

\section{Conclusion}

The issue of refugees is a very salient one in the present global context. Unprecedented numbers of people are leaving their nation-states of origin for various reasons. Although the international refugee regime exists to address this issue, legal treatment of the issue is likely to be very much extra-legal as the issue is fundamentally political. Moral and economic issues related to refugees also have tangible political implications in relation to whether states adopt pro-refugee policies (and act consistently with the international refugee regime) or anti-refugee policies (which are not consistent with the international refugee regime). Refugee flows have arguably always been a matter of high politics, ${ }^{98}$ and as refugee scholar Goodwin-Gill notes, it is "unrealistic to imagine that the problem of refugees can ever be entirely non-political." ${ }^{99}$ I offer two reasons for this - firstly, the structure of the international refugee regime is such that nation--

Halpin, “Conceptual Collisions," 511.

William Twining, General Jurisprudence: Understanding Law from a Global Perspective

(Cambridge University Press, 2009), 369.

Raz, "Why the State?" 2.

Raz, "Why the State?" 23.

Raz, "Why the State?" 22.

MacCormick, Institutions of Law, 254.

Cindy Horst, "Forced migration: morality and politics," Ethnic and Racial Studies 41, no. 3 (2018): 443 .

Guy S. Goodwin-Gill, “The Politics of Refugee Protection," Refugee Survey Quarterly 27, no. 1 (2008): 21 . 
states are the key actors - and that means the legal implementation of the regime is highly dependent on the political context. The differing legal positions correspond to diametrically opposed ideological and moral positions towards refugees - thus, states can, and do, act inconsistently with the international refugee regime where it is seen as being in their interest to do so. Secondly, the inherent nature of the refugee issue itself is highly-charged, going to the very heart of cherished ideas of citizenship, identity and affinity. Unlike relatively apolitical areas of law like the law of contracts or international commercial arbitration, refugees raise uncomfortable political, moral and economic questions. The net effect of all of this is to create a stark "disharmony of law and social reality." ${ }^{100}$ Perhaps this is an example of a global legal phenomenon that, against the trends of globalization, highlights the importance rather than irrelevance of the nation-state paradigm. We should thus acknowledge the tension between "universalism and particularism, between cosmopolitanism and nationalism," 101 and ideally, strike a balance between the two. ${ }^{102}$ A truly cosmopolitan approach towards refugees is, however, unlikely to materialize so long as nation-states remain the primary actors in the global legal and political order.

\section{Bibliography}

Afilalo, Ari and Dennis Patterson. "Statecraft, Trade and Strategy: Toward a New Global Order." In Theorising the Global Legal Order, edited by Andrew Halpin and Volker Roeben. Hart Publishing, 2009.

Agren, David. "Bad hombres': reports claim Trump spoke of sending troops to Mexico," The Guardian, February 2, 2017, https://www.theguardian.com/us-news/2017/ feb/o2/bad-hombres-reports-claim-trump-threatened-to-send-troops-to-mexico.

Almond, Brenda. "Border Anxiety: Culture, Identity and Belonging." Philosophy 91, no. 4 (2016): 463-81.

Altman, Matthew C. "The Limits of Kant's Cosmopolitanism: Theory, Practice, and the Crisis in Syria." Kantian Review 22, no. 2 (2017): 179-204.

Ataner, Attila. "Refugee Interdiction and the Outer Limits of Sovereignty." Journal of Law \& Equality 3, no. 1 (2004): 7-29.

Baban, Feyzi and Kim Rygiel, "Living with Others: Fostering Radical Cosmopolitanism through Citizenship Politics in Berlin." Ethics \& Global Politics 10, no. 1 (2017): 98-116.

Bauder, Harald. "Understanding Europe's Refugee Crisis: A Dialectical Approach." Geopolitics, History and International Relations 8, no. 2 (2016): 64-75.

BBC, “Trump Travel Ban Comes into Effect for Six Countries.” June 30, 2017, http://www. bbc.com/news/world-us-canada-4045236o.

100 Hathaway, “A Reconsideration," 180.

101 Almond, "Border Anxiety," 478.

102 Almond, "Border Anxiety," 478. 
Benjamin, Andrew. "Refugees, Cosmopolitanism and the Place of Citizenship." Architectural Theory Review 7, no. 2 (2002):101-16.

Betts, Alexander, Gil Loescher, James Milner and Gilburt Damian Loescher. UNHCR: The Politics and Practice of Refugee Protection. New York: Routledge, 2012.

Calloni, Marina. "Cosmopolitanism and the Negotiation of Borders." Irish Journal of Sociology 20, no. 2 (2012): 153-74.

Chang, Ruth. "Incommensurability (and Incomparability)." In The International Encyclopedia of Ethics, edited by Hugh LaFollette. Wiley, 2013.

Chia, Joyce, Jane McAdam and Kate Purcell, "Asylum in Australia: 'Operation Sovereign Borders' and International Law." Australian Yearbook of International Law $3^{2}$ (2014): 33-64.

Chimni, Bhupinder S. "The Geopolitics of Refugee Studies: A View from the South." Journal of Refugee Studies 11 (1998): 350-74.

Cindy Horst, "Forced migration: morality and politics." Ethnic and Racial Studies 41, no. 3 (2018): 440-47.

Dauvergne, Catherine. "The Dilemma of Rights Discourses for Refugees." University of New South Wales Law Journal 23 (2000): 56-74.

Gammeltoft-Hansen, Thomas and Nikolas F. Tan, "The End of the Deterrence Paradigm - Future Directions for Global Refugee Policy." Journal on Migration and Human Security 5, no. 1 (2017): 28-56.

Gerrard, Jessica. "The refugee crisis, non-citizens, border politics and education." Discourse: Studies in the Cultural Politics of Education 38, no. 6 (2017): 880-91.

Gibney, Matthew J. The Ethics and Politics of Asylum: LiberalDemocracy and the Response to Refugees. Cambridge University Press, 2004.

Gillespie, John. "Developing a Framework for Understanding the Localisation of Global Scripts in East Asia." In Theorising the Global Legal Order, edited by Andrew Halpin and Volker Roeben. Hart Publishing, 2009.

Grey, Colin. "Refugee Law and Its Corruptions." Canadian Journal of Law and Jurisprudence 30, no. 2 (2017): 339-62.

Guiraudon, Virginie and Gallya Lahav, "A Reappraisal of the State Sovereignty Debate: The Case of Migration Control." Comparative Political Studies 33, no. 2 (2000): 163-95.

Guy S. Goodwin-Gill, “The Politics of Refugee Protection.” Refugee Survey Quarterly 27, no. 1 (2008): 8-23.

Halpin, Andrew. "Conceptual Collisions." Jurisprudence 2, no. 2 (2011): 507-19.

Halpin, Andrew. "Ideology and Law." Journal of Political Ideologies 11, no. 2 (2006): 15368.

Hasegawa, Ko. "Incorporating Foreign Legal Ideas through Translation." In Theorising the Global Legal Order, edited by Andrew Halpin and Volker Roeben. Hart Publishing, 2009 .

Hathaway, James C. "A Reconsideration of the Underlying Premise of Refugee Law." Harvard International Law Journal 31 (1990): 129-84. 
Hathaway, James C. The Rights of Refugees Under International Law. Cambridge University Press, 2005.

Hindess, Barry. "Divide and Rule - The International Character of Modern Citizenship." European Journal of Social Theory 1, no. 1 (1998): 57-70.

Hirvonen, Ari. "Fear and Anxiety: The Nationalist and Racist Politics of Fantasy." Law Critique 28, no. 3 (2017): 249-65.

Kattago, Siobhan. "The End of the European Honeymoon?: Refugees, Resentment and the Clash of Solidarities." Anthropological Journal of European Cultures 26, no. 1 (2017): 35-52.

Keyes, Elizabeth. "Unconventional Refugees." American University Law Review 67 (2017): 89-164.

Kim, Seunghwan. "Non-Refoulement and Extraterritorial Jurisdiction: State Sovereignty and Migration Controls at Sea in the European Context." Leiden Journal of International Law 30, no. 1 (2017): 49-70.

Kritzman-Amir, Tally and Thomas Spijkerboer, "On the Morality and Legality of Borders: Border Politics and Asylum Seekers." Harvard Human Rights Journal 26, no. 1 (2013): $1-38$.

Kritzman-Amir, Tally. "Not in My Backyard: On the Morality of Responsibility Sharing in Refugee Law." Brooklyn Journal of International Law 34 (2009): 355-93.

$\mathrm{Ku}$, Julian and John Yoo. "Globalization and Sovereignty." Berkeley Journal of International Law 31 (2013): 210-35.

MacCormick, Neil. Institutions of Law: An Essay in Legal Theory. Oxford University Press, 2007.

Mansfield, James. "Extraterritorial Application and Customary Norm Assessment of Non-Refoulement: The Legality of Australia's Turn-Back Policy." The University of Notre Dame Australia Law Review 17 (2015): 18-58.

Momin, Suman. "A Human Rights Based Approach to Refugees: A Look at the Syrian Refugee Crisis and the Responses from Germany and the United States." Duke Forum for Law and Social Change 9 (2017): 55-80.

Quah, Euston and Raymond Toh. Cost-Benefit Analysis: Cases and materials. Routledge, 2011.

Raz, Joseph. "Why the State?," King's College London Law School Research Paper 2014-38, 2013.

Ruist, Joakim. "The Fiscal Cost of Refugee Immigration: The Example of Sweden." Population and Development Review 41, no. 4 (2015): 567-81.

Schuck, Peter H. "Refugee Burden-Sharing: A Modest Proposal." Yale Journal of International Law 22 (1997): 243-98.

Singer, Peter. "Famine, Affluence, and Morality." Philosophy and Public Affairs 1, no. 1 (1972): 229-43.

Singer, Peter. Practical Ethics, $2^{\text {nd }}$ ed. Cambridge: Cambridge University Press, 1993.

Trauner, Florian and Jocelyn Turton, "'Welcome culture": The emergence and transformation of a public debate on migration." Österreichische Zeitschrift für Politikwissenschaft 46, no. 1 (2017): 33-42. 
Twining, William. "Social Science and Diffusion of Law." Journal of Law and Society 32, no. 2 (2005): 203-40.

United Nations General Assembly, "Convention Relating to the Status of Refugees." 28 July 1951, accessed January 14, 2020, http://www.unhcr.org/3b66c2aa1o.pdf.

United Nations General Assembly, "Protocol Relating to the Status of Refugees." 31 January 1967, accessed January 14, 2020, http://www.unhcr.org/3b66c2aa1o.pdf.

United Nations High Commissioner for Refugees. "Global Trends-Forced Displacement in 2016," last modified 19 June 2017, accessed January 14, 2020, http://www.unhcr. org/5943e8a34.pdf.

United Nations High Commissioner for Refugees. "Non-Governmental Organizations," accessed January 14, 2020, http://www.unhcr.org/non-governmental-organizations.html.

Waldron, Jeremy. "Are Sovereigns Entitled to the Benefit of the International Rule of Law?" European Journal of International Law 22, no. 2 (2011): 315-43.

Walling, Carrie Booth. "Human Rights Norms, State Sovereignty and Humanitarian Intervention." Human Rights Quarterly 37 (2015): 383-13.

Wellman, Christopher H. "Freedom of Movement and the Rights to Enter and Exit." In Migration in Political Theory: The Ethics of Movement and Membership, edited by Sarah Fine and Lea Ypi. Oxford University Press, 2016.

Wellman, Christopher H. "Immigration and Freedom of Association." Ethics 119, no. 1 (2008): 109-41.

White, Stuart. "Freedom of Association and the Right to Exclude." Journal of Political Philosophy 5 (1997): 373-91.

William Twining, General Jurisprudence: Understanding Law from a Global Perspective. Cambridge University Press, 2009.

Worster, William Thomas. "The Contemporary International Law Status of the Right to Receive Asylum." International Journal of Refugee Law 26 (2014): 477-9o.

Yamagishi, Toshio, Yang Li, Haruto Takagishi, Yoshie Matsumoto and Toko Kiyonari. "In Search of Homo Economicus." Psychological Science 25, no. 9 (2014): 1699-711.

Ivan Ng Yan Chao is a postgraduate student research assistant at the S. Rajaratnam School of International Studies, Nanyang Technological University, Singapore, where he is a candidate for a Master of Science in Strategic Studies. He holds a Bachelor of Laws and a Master of Arts (Southeast Asian Studies) from the National University of Singapore. His research interests broadly span ethnic politics, security and migration.

Acknowledgments: The author would like to thank Professor Andrew Halpin from the National University of Singapore for his invaluable guidance and teaching, as well as for the extremely helpful comments and suggestions from the anonymous reviewers. 


\title{
Космополітанизм та Націоналізм: Критика Ефективності Міжнародного Режиму Біженців
}

\author{
Іван Нг Ян Чао \\ асистент дослідника \\ Нан'янзький технологічний університет, Сингапур
}

\begin{abstract}
Анотація
За останні п'ять років спостерігалося різке зростання важливості питання біженців, особливо в Європі, але і в інших частинах світу. Пройшло вже майже сімдесят років з того часу, як було створено посаду Верховного комісара ООН у справах біженців і підписаний перший міжнародний договір, який регулює питання біженців. Ця стаття присвячена аналізу міжнародного правового механізму регулювання питання біженців і відзначає його неефективність, оскільки біженці є невід’ємним об’єктом великої політики-біженці є фундаментальним політичним суб'єктом політики. Моральні та економічні обгрунтування сучасного режиму регулювання питань біженців також викликають багато суперечок, які точаться передусім в політичній площині. Міжнародно-правовий режим регулювання питань біженців ще не скоро може стати ефективним, особливо допоки національні держави залишаться основними гравцями в міжнародному світовому порядку. Міжнародний режим правового регулювання питань біженців вимагає своєї реалізації на практиці та втілення з боку держав, водночас політичні, моральні та економічні умови, що існують між різними державами, включеними у процес регулювання питання біженців, послаблює ефективність цієї системи.
\end{abstract}

Ключові слова: біженці, міграція, політика, міжнародне право, філософія, національні держави 